\title{
A perfect storm: Open surgical approach to iatrogenic abdominal aortic injury developed during percutaneous nephrostomy
}

\author{
Beklenmedik bir sonuç: Perkütan nefrostomi sırasında gelişen iyatrojenik \\ abdominal aort yaralanmasında açık cerrahi yaklaşım
}

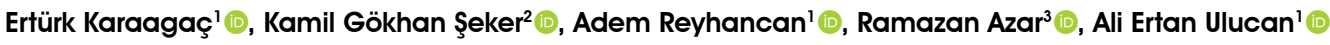 \\ 'Department of Cardiovascular Surgery, Muş State Hospital, Muş, Turkey \\ ${ }^{2}$ Department of Urology, Muș State Hospital, Muș, Turkey \\ ${ }^{3}$ Department of General Surgery, Muş State Hospital, Muş, Turkey
}

\begin{abstract}
Percutaneous nephrostomy catheter insertion allows the diagnosis and treatment of many pathologies from kidney failure to infection and obstruction. Vascular injuries are considered one of the complications of percutaneous interventions and are rarely seen after percutaneous nephrostomy catheter insertion. Herein, we report the first case of the successful surgical treatment of iatrogenic abdominal aortic injury after percutaneous nephrostomy catheter insertion in a 78-year-old female patient who developed hydroureteronephrosis and acute renal failure due to obstructive ureteral stone in the right proximal ureter.
\end{abstract}

Keywords: Aorta, iatrogenic, injury, nephrostomy, percutaneous.

Image-guided interventions have allowed for minimally invasive treatment of many common diseases, obviating the need for open surgery. While percutaneous interventions usually represent a safer approach than traditional surgical alternatives, complications may arise. Vascular injuries are considered one of the complications of percutaneous interventions and are rarely seen after percutaneous nephrostomy (PCN) catheter insertion. ${ }^{[1]}$ The kidney, which is a highly vascularized organ, can be injured during these percutaneous interventions and may be caused bleeding to a degree that disrupts hemodynamics. ${ }^{[1,2]}$ In the postoperative follow-up, particularly in the presence of $\mathrm{PCN}$ catheter
$\ddot{O} Z$

Perkütan nefrostomi kateter yerleştirilmesi, böbrek yetmezliğinden enfeksiyon ve tıkanıklığa kadar pek çok patolojinin tanı ve tedavisine olanak sağlar. Vasküler yaralanmalar, perkütan girişimlerin komplikasyonlarından biri olarak kabul edilir ve perkütan nefrostomi kateteri takıldıktan sonra nadiren görülür. Bu makalede, sağ proksimal üreterde tıkayıcı üreter taşına bağlı olarak hidroüreteronefroz ve akut böbrek yetmezliği gelişen 78 yaşında bir kadın hastada, perkütan nefrostomi kateteri takılması sonrasi saptanan iyatrojenik abdominal aort yaralanmasının ilk başarılı cerrahi tedavisi sunuldu.

Anahtar sözcükler: Aort, iyatrojenik, yaralanma, nefrostomi, perkütan.

dysfunction and hemodynamic instability, it should not be overlooked. In such cases, besides providing hemodynamic stability quickly, the location and degree of vascular injury should be determined by imaging methods and the patient should be prepared for an emergency surgical intervention.

In this article, we, for the first time, present the successful open surgical treatment of iatrogenic abdominal aortic injury developed during PCN catheter insertion in an advanced age female patient in whom hydroureteronephrosis and acute renal failure occurred due to an obstructive ureteral stone in the right proximal ureter.

Received: November 20, 2020 Accepted: February 17, 2021 Published online: April 26, 2021

Correspondence: Ertürk Karaagaç, MD. Muş Devlet Hastanesi Kalp ve Damar Cerrahisi Kliniği, 49200 Muş, Türkiye.

Tel: +90 506 - 5870470 e-mail: erturkkaraagac@gmail.com 

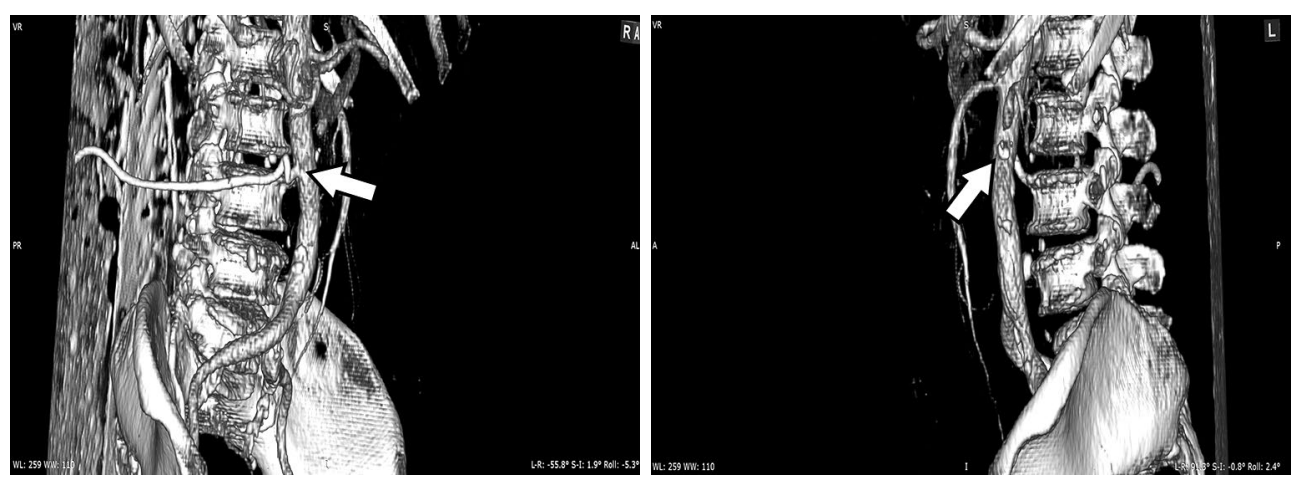

Figure 1. The tip of PCN catheter was seen to injure aorta $2 \mathrm{~cm}$ below right renal artery outlet on $3 \mathrm{D}$ reconstruction of CT. White arrows showing abdominal aortic injury due to catheter.

PCN: Percutaneous nephrostomy; 3D: Three dimensional; CT: Computed tomography.

\section{CASE REPORT}

A 78-year-old female patient was admitted to the emergency department with right flank pain and anuria. Right hydroureteronephrosis and acute renal failure due to obstructive ureteral stone were detected. The patient had no additional comorbidities other than recurrent urinary stone disease and left atrophic kidney. Vital signs of the patient on admission were as follows: body temperature $37.8^{\circ} \mathrm{C}$, blood pressure $140 / 90 \mathrm{mmHg}$, respiratory rate 20 breaths/min, heart rate $98 \mathrm{bpm}$, and oxygen saturation $96 \%$. Blood test results were as follows: white blood cell count: $15,500 \mu \mathrm{L}$, hemoglobin: $11.5 \mathrm{~g} / \mathrm{dL}$, serum blood urea nitrogen: $107 \mathrm{mg} / \mathrm{dL}$, creatinine: $5.34 \mathrm{mg} / \mathrm{dL}$, potassium: $7.2 \mathrm{mmol} / \mathrm{L}$, and C-reactive protein, $97.3 \mathrm{mg} / \mathrm{L}$.

Interventional radiology was consulted for an emergent PCN catheter insertion. The PCN catheter (10F-pigtail) was inserted under ultrasound guidance by the interventional radiologist. After the procedure, dysfunction was observed in the PCN catheter and hypotension developed. A non-contrast computed tomography (CT) confirmed the tip of catheter in the abdominal aorta. The patient was immediately evaluated with contrast-enhanced CT angiography, after the hemodynamic stability was achieved. In addition to the retroperitoneal hematoma on CT angiography, the tip of the catheter was seen to injure the aorta $2 \mathrm{~cm}$ below the right renal artery outlet (Figure 1). The tip of the catheter was within the infrarenal abdominal aortic lumen (Figure 2). Upon these findings, the patient was urgently taken into operation. An open surgery was planned for the patient to evaluate possible injuries of other retroperitoneal structures due to the insertion site and course of the catheter, and additionally, considering the hemodynamic instability, acute kidney failure, and the degree of aortic injury. Under general anesthesia, the abdominal aorta was reached transperitoneally
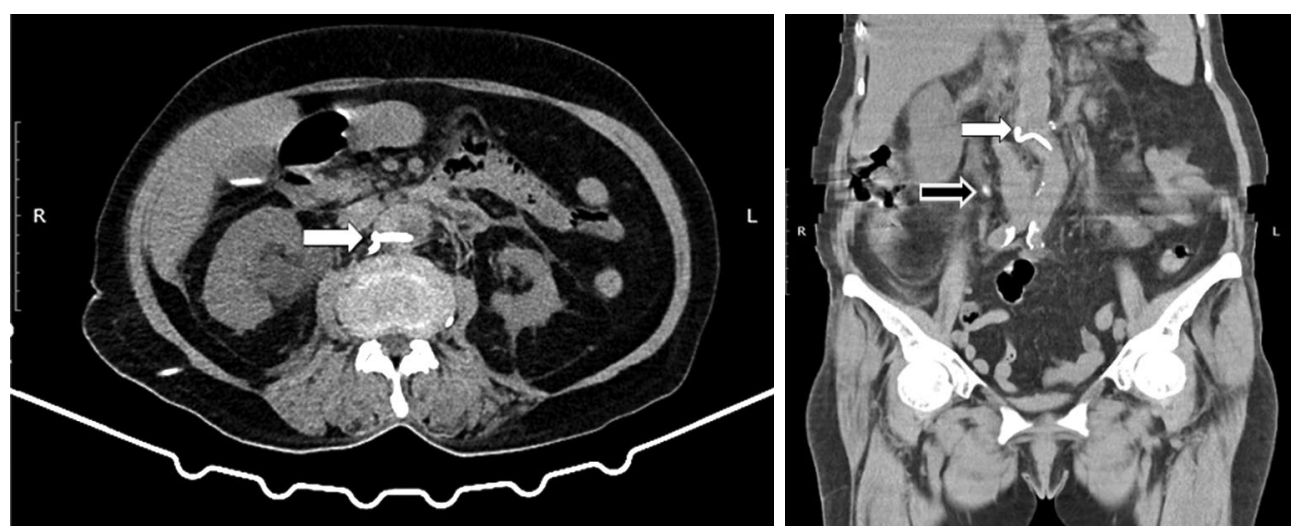

Figure 2. The tip of the catheter was seen within infrarenal abdominal aortic lumen on non-contrast CT. White arrows showing tip of the catheter; black arrow showing proximal ureteral stone.

CT: Computed tomography. 
with a midline incision. Abdominal aorta was carefully released from the surrounding tissues and inferior vena cava. It was safely controlled from the left renal artery line and inferior mesenteric artery line. The nephrostomy catheter was seen in the retroperitoneal region. The abdominal aorta was, then, clamped following heparinization and the catheter was removed from the lumen. The injury of aorta was repaired primary with $4 / 0$ prolene suture. Then right ureterolithotomy and D-J stent placement was performed and a proximal ureteral stone was removed. After the bleeding control, the nephrostomy catheter was removed and two abdominal drains were inserted. The incisions were closed in the anatomical planes and the operation was ended. The patient was extubated after the operation and was followed by abdominal and urinary tract ultrasonography in the postoperative period. The patient was discharged on postoperative Day 7, as acute renal injury was regressed and hemodynamic stability was achieved. The D-J stent was removed in the first postoperative month. A written informed consent was obtained from the patient.

\section{DISCUSSION}

Vascular complications related to the insertion of a PCN catheter have been reported in the literature as case reports and case series. However, there is no injury to the abdominal aorta after PCN catheter insertion in the literature. Most case reports and series include renal vein, inferior vena cava, and right atrium. ${ }^{[3,4]}$ To the best of our knowledge, this case report is the first publication reported in the literature.

In a study by Kaskarelis et al., ${ }^{[2]} 341$ patients underwent 1,036 percutaneous renal interventions (including nephrostomy, ureteral stent placement or catheter replacement). Fatal retroperitoneal bleeding was experienced in only one patient, while $1.2 \%$ of the procedures resulted in permanent hematuria. Also, no major vascular injuries were observed.

Early detection of a misplaced PCN catheter is important to prevent dramatic complications. Therefore, the pelvicalyceal system must be checked with antegrade pyelography in the first step after nephrostomy catheter insertion. ${ }^{[4]}$ An iatrogenic injury of the abdominal aorta may lead to catastrophic consequences. Its early recognition and repair is, thus, of vital importance.

Iatrogenic injuries of the abdominal aorta should not be overlooked in the presence of nephrostomy catheter dysfunction and hemodynamic instability. Where feasible, the use of a stent graft allows for rapid coverage of the aortic lesion, with immediate cessation of bleeding and relatively low risk of perioperative complications compared to open repair. ${ }^{[5]}$ Open operative treatment includes direct flap repair, thromboendarterectomy, and aortic replacement using a prosthetic graft. ${ }^{[6]}$ Complications of open repair are high and mortality rate is reported to be $27 \% .{ }^{[7]}$

If hemodynamic stability could have been preserved, the catheter removal, waiting and performing endovascular surgery, when necessary, would be an option. However, the additional contrast dose to be given to the patient with acute renal failure would cause further deterioration of renal functions and the need for permanent hemodialysis. In addition, catheter pull-out strategy could have caused another injury due to the size (10F) and structure (pigtail) of the catheter. During the consultation with the department of urology, the primary reason causing acute renal failure was deemed as an obstructive ureteral stone requiring ureterolithotomy. Also, this situation supported the necessity of open surgical treatment. The improvement of acute renal injury and absence of additional vascular and urological pathology in the postoperative followup of the patient highlight the importance of the multidisciplinary surgical treatment. That is why, as in this case that is not suitable for endovascular treatment, we believe that open surgical repair is the first option if there is a catheter in the aortic lumen, accompanied by a multidisciplinary assessment.

In conclusion, percutaneous nephrostomy catheter insertion, despite being a minimally invasive procedure, it rarely potentially carries a risk of major vascular injury. Abdominal aortic injury is a rare complication of percutaneous nephrostomy and may require open surgery and direct vascular injury repair.

\section{Declaration of conflicting interests}

The authors declared no conflicts of interest with respect to the authorship and/or publication of this article.

\section{Funding}

The authors received no financial support for the research and/or authorship of this article.

\section{REFERENCES}

1. Lessne ML, Holly B, Huang SY, Kim CY. Diagnosis and management of hemorrhagic complications of interventional radiology procedures. Semin Intervent Radiol 2015;32:89-97.

2. Kaskarelis IS, Papadaki MG, Malliaraki NE, Robotis ED, Malagari KS, Piperopoulos PN. Complications of percutaneous nephrostomy, percutaneous insertion of ureteral endoprosthesis, and replacement procedures. Cardiovasc Intervent Radiol 2001;24:224-8. 
3. Chen XF, Chen SQ, Xu LY, Gong Y, Chen ZF, Zheng SB. Intravenous misplacement of nephrostomy tube following percutaneous nephrolithotomy: Three new cases and review of seven cases in the literature. Int Braz J Urol 2014;40:690-6.

4. Mazzucchi E, Mitre A, Brito A, Arap M, Murta C, Srougi M. Intravenous misplacement of the nephrostomy catheter following percutaneous nephrostolithotomy: two case reports. Clinics (Sao Paulo) 2009;64:69-70.

5. Monzio-Compagnoni N, Aseni P, Romani F. Emergency aortic control for pedicle screw misplacement during spinal fixation. Ann Vasc Surg 2020;66:669.e1-669.e3.

6. Berthet JP, Marty-Ané CH, Veerapen R, Picard E, Mary H, Alric P. Dissection of the abdominal aorta in blunt trauma: Endovascular or conventional surgical management? J Vasc Surg 2003;38:997-1003.

7. Gunn M, Campbell M, Hoffer EK. Traumatic abdominal aortic injury treated by endovascular stent placement. Emerg Radiol 2007;13:329-31. 